\title{
British Press System: Press Regulation and Accountability
}

How to regulate the press is arguably the foremost issue in media reform debates. Therefore, this chapter examines the history of press regulation in the UK as a way of highlighting recurrent trends in efforts at reforming press regulation and the outcomes of such attempts. To this end, this chapter discusses the history of press regulation in Britain, the British press system and relevant aspects of the Leveson Inquiry. The setting up of an inquiry to investigate press standards did not begin with the Leveson Inquiry. For approximately 70 years (at the time of writing), a number of commissions have been set up with a mandate to make the press accountable. These include the Royal Commissions on the press (RCP) 1949, 1962 and 1977 along with two Calcutt Committees (RCP 1949, 1962; Curran and Seaton 2010; Harcup 2014, p. 46). The 1949 Royal Commission on the press was set up by the British government to investigate the increasing concentration of ownership of newspaper and periodicals, and to promote free expression of opinion through the press (Frost 2007; Curran and Seaton 2010). Ironically, the 1949 Royal commission took for granted the power of media proprietors to determine editorial policy (ibid.).

The Press Commission declared that media proprietors should be free to run their publications the way they please on the basis that "proprietors had the right to safeguard their financial investment in a high-risk industry" like the press (Curran and Seaton 2010, p. 328). As Curran and Seaton $(2010$, p. 328$)$ pointed out, "this hands-off approach assumed that

B. Ogbebor, British Media Coverage of the Press Reform Debate, https://doi.org/10.1007/978-3-030-37265-1_3 
chain ownership will not develop into a major problem". The position of the 1949 Royal Commission of the press was condemned by the 1962 Press Commission. By that time, the share circulation controlled by media magnates had increased dramatically in all parts of the press. The three leading proprietors' share of the national daily press had risen to 89 per cent. The Commission acknowledged that these were obvious signs of concentration of media ownership; but after much deliberation, the Commission concluded that "there was no acceptable legislative or fiscal method of controlling the economic forces to ensure diversification of newspapers" (Frost 2007, p. 215). The 1977 Press Commission was very vocal in its condemnation of the growing trend of media concentration (Curran and Seaton 2010). It declared that the acceleration of media chain ownership since 1962 was unparalleled; "new acquisitions had also resulted in the same three proprietors dominating both the national daily and the Sunday markets" (Curran and Seaton 2010, p. 319). The 1977 Press Commission was critical of this development. For this Commission, "free press" was not synonymous with newspaper publishers running their papers the way they pleased without due regard for the good of society.

Despite these condemnations, the concentration of press ownership in the UK has remained high in comparison with other European countries. All three commissions on the British press (1949, 1962 and 1977) examined the issue of concentration of media ownership and its potential to cripple press accountability, but the closest they got to tackling the problem was to advocate anti-monopoly measures which did not work (Curran and Seaton 2010, p. 338). This failure has been attributed to policymakers' "fear of the press" because recurrently, when proposals are made on how to regulate the press and control media ownership, they are either not adopted or not implemented. The opposition of publishers to any form of statutory regulation is another recurrent trend during attempts to regulate the press.

The British press operates a system of self-regulation. Self-regulation refers to a system where an industry sets up a body to "control standards in the industry" (Frost 2007, p. 214). Such a body serves as a way of proving to their consumers that they are maintaining high standards. However, this does not appear to have worked well for the British press. Many people have condemned the ethical standards of the press in Britain (Frost 2007; Petley 2013). There has been a barrage of accusations on invasion of privacy, inaccurate reporting and other forms of malpractice (Spark and Harris 2010, p. 193; Cathcart 2018). Some have called for statutory 
regulation of the British Press (O'Malley and Soley 2000, p. 178; Frost 2007 , p. 236). Statutory regulation is a system of regulation that is set up by law and supported by government (Frost 2007, p. 250). The British press has continued to oppose statutory regulation of the press. The Council (which became the Press Council from 1963) was reluctantly set up in 1953 following threats of statutory regulation resulting from harmful journalism practices (Curran and Seaton 2010, p. 334).

Further threats led to the setting up of the Code of Conduct for journalists and after fresh threats the Press Complaints Commission (PCC) was set up in 1991 (ibid.). The PCC was described by many as "lacking teeth" (effectiveness) and ambition (Leveson Inquiry 2012a, p. 555, para. 3.34). Lord Justice Leveson, in his inquiry into the practices, culture and ethics of the media, declared that the PCC had failed in its responsibility as a self-regulatory organ of the press (Leveson 2012b, p. 12, paras. 41-46). Several commentators agree that the PCC failed as a regulator (Bloy 2012, pp. 19-20; Carney 2012, p. 323). The PCC's investigation of the phone hacking scandal at the News of the World is a case in point. When Clive Goodman, the News of the World Royal correspondent, and Glen Mulcaire, a private detective employed by the newspaper, were jailed for phone hacking, the PCC investigated the use of subterfuge, phone tapping and compliance with the Editors' Code of Practice but its report was widely criticised as a "whitewash" (Bloy 2012, p. 18). Andy Coulson resigned as Editor of the News of the World, and on that basis, the PCC concluded that he was no longer answerable to the regulatory body because its jurisdiction covered only journalists working for publications that subscribed to the self-regulatory system. The courts later crossexamined Andy Coulson and found him guilty of plotting to intercept voicemails between 2000 and 2006. He was sentenced to 18 months in prison (BBC News 2014).

Having had three major commissions and a PCC that could not ensure an accountable press, the Leveson Inquiry, which followed the News of the World phone hacking scandal, was embraced as a perceived opportunity to correct about 70 years of an ineffective press regulatory system in Britain (Leveson 2012b, p. 3, para. 1). The Leveson Inquiry was set up by the British government on 13 July 2011 to investigate the role of the press and the police in the News of the World phone hacking scandal (National Archive, Leveson Inquiry 2012a). The scope of the inquiry went beyond the scandal to include broader issues of press and police accountability. The inquiry was triggered by public outrage against the News of the World 
for its involvement in wide-scale phone hacking, particularly the hacking of the mobile phone of the murdered school girl known as Milly Dowler (Leveson 2012b, p. 3, para. 1). The inquiry which began on 14 November 2011 had as its mandate an inquiry into the culture, practices and ethics of the British press, particularly its relationship with the public, the police and politicians.

The Leveson Inquiry has been described as "the most concentrated look at the press" the UK has ever known (Leveson 2012b, p. 3, para. 3). In a space of about nine months, 337 witnesses gave evidence in person in addition to about 300 whose statements were read into the record (ibid.). Among them were victims of press abuse, newspaper reporters, management and proprietors as well as police officers and politicians. The Inquiry's report, which was released on 29 November 2012, contained proposals for future press regulation of the UK. I do not attempt to capture all information in the 2000-page report but will highlight those aspects that are relevant to discussions in this book. In the Inquiry's report, Lord Justice Leveson recommended a system of press regulation referred to as independent self-regulation. This system requires the establishment of an independent regulatory body which should promote high standards of journalism and protect the rights of individuals. In the words of Lord Justice Leveson, the independent self-regulatory body should:

Set standards, both through a code and in relation to governance and compliance ... hear individual complaints against its members about breach of its standards and order appropriate redress while encouraging individual newspapers to embrace a more rigorous process for dealing with complaints internally; take an active role in promoting high standards, including having the power to investigate serious or systemic breaches and impose appropriate sanctions; and provide a fair, quick and inexpensive arbitration service to deal with any civil law claims based upon its members' publications. (Leveson 2012b, pp. 14-15, paras. 56-57)

The appointment of the chairman and members of the independent regulatory body should be independent (Leveson 2012b, p. 15, para. 58). This, he said, can be achieved through the establishment of an independent appointments panel which can include one current editor but should have a majority of persons who are independent of both press and government (ibid.). The board of the regulatory body should include sufficient number of people with experience of the industry, such as former editors 
and senior or academic journalists (Leveson 2012b, p. 15, para. 59). Those who cannot serve on the board are serving editors or members of the House of Commons or the government. The appointment process should be fair and open (ibid.). The idea here was to make the board independent of the industry while ensuring that it does not lack knowledge about its operations.

According to the Leveson Report, funding for the new regulatory body should "be agreed between the regulatory body and the industry with security of funding over a reasonable planning period" (ibid.). This ought to take into account "the cost of fulfilling the obligations of the regulator as well as the commercial pressures on the industry" (ibid.). This system would also require the setting up of a Code Committee whose role would be to advise the new regulator on the promulgation of a code of practice for the industry. This committee, according to the Inquiry's report, should include serving editors and engage with the public to review the code. The report also suggested that the new regulatory body be encouraged to deal with complaints even where there is an option of legal action. It is also to issue warning notifications to the press on behalf of persons who become "subjects of unwanted press intrusion and ensure that newspapers are held accountable for all material they print" no matter from where it is sourced.

Lord Justice Leveson recommended that the new independent selfregulatory body provide guidance on interpretation of "the public interest" (Leveson 2012b, p. 15, para. 62). This service will include offering "voluntary pre-publication advice to editors" in need of guidance on how to interpret "the public interest" in a particular case, before they take a decision on whether to publish the story. This service is to be carried out without notifying the subject of the story. The independent self-regulatory body is also expected to create a whistle-blowing hotline as well as ensure that member organisations include a "conscience clause" in their employment contracts with journalists. The "conscience clause" is meant to protect journalists who feel that they are being compelled to do things that are "unethical or against the code".

To encourage publishers to sign up to an acceptable self-regulatory establishment based on the Inquiry's guidelines, Lord Justice Leveson recommended that the independent regulatory body be given the power to provide an arbitration service that would be recognised by the courts (Leveson 2012b, p. 16, paras. 66-67). Members of this arbitration body, he suggested, should be retired judges or senior lawyers who are experts in media law and whose charges would be paid by the media outfit 
concerned (ibid.). They are to resolve disputes through cross-examination, striking out frivolous claims while resolving those with merit. The aim is to provide an incentive through the costs of civil litigation (ibid.). The Inquiry also recommended that if a publisher denies a claimant the opportunity of a cheap and fast arbitration because of his refusal to belong to the regulatory system, then the Civil Procedure Rules could give the court permission to deny that publisher its costs of litigation even if he wins the case, because resolving the issue could have been cheaper for all parties involved if the publisher had signed up with the regulator. On the other hand, if a newspaper that refused to subscribe to the new regulatory body is found guilty of infringing the rights of a claimant, such a newspaper would be subjected to payment of exemplary damages (Leveson 2012b, p. 16, para. 68).

Similarly, if a claimant takes advantage of his or her financial power and compels a newspaper who is a member of the self-regulatory body into a litigation, that newspaper would have the right to argue that "having provided a recognised low cost arbitral route, that claimant, even if successful, should be deprived of costs", because they refused the cheap route to justice offered by the proposed regulatory body (Leveson $2012 \mathrm{~b}, \mathrm{p} .17$, para. 69). Of all the recommendations made by the Inquiry, what emerged as the most controversial was its suggestion that the proposed independent self-regulatory system be underpinned by legislation (Leveson Report 2012 b, p. 17, para. 70). This became the nucleus of a number of arguments that followed the release of the Leveson Report.

Following Lord Justice Leveson's proposal that the PCC be replaced by a new independent regulatory body underpinned by statute, the PCC was closed on 8 September 2014. The Independent Press Standards Organisation (IPSO), which describes itself as "the independent regulator for the newspaper and magazine industry in the UK", began on the same day (PCC 2017; IPSO 2016). The PCC website described IPSO as a replacement of the PCC (PCC 2017). By 2015, over 1500 newspapers and magazines had registered with IPSO. However, some scholars argue that IPSO is not much different from the PCC with regard to ensuring press accountability (Cathcart 2018, 2019). Lord Justice Leveson's recommendation led to the setting up of the Royal Charter on self-regulation of the press in 2013 , following negotiations and heated debates involving the three main political parties in the country at the time (the Conservatives who were in a coalition government with the Liberal Democrats, and the Labour Party), Hacked Off (a campaign organisation representing victims 
of press abuse) and representatives of the press. A final version of the government's Royal Charter was published on 11 October 2013 and approved by the Privy Council on 30 October 2013 (DCMS and Miller 2013, n.p.). IPSO refused to sign up to the Royal Charter on Press Regulation because it was underpinned by statute. It posits that a press regulatory body with any form of statutory backing is a slippery slope to licensing of the press (IPSO 2016). On 25 October 2016, the Independent Monitor for the Press (IMPRESS) became the first press regulator to be recognised by the Press Recognition Panel of the Royal Charter on Press Regulation (IMPRESS 2016). By 2019, 129 publications had signed up to the regulator (IMPRESS 2019).

In 2018, despite several calls from media reform campaigners not to do so, the Conservative government rescinded on its decision to go ahead with the second part of the Leveson Inquiry which was to scrutinise the relationship between the press and the police. The government's reason for doing so was that the "the media landscape had changed and justice had been served through the criminal trials of many of those involved" (Waterson 2018). The Leveson Inquiry was designed to be in two parts; the first part focused on the press' relationship with the public and politicians. The second part of the inquiry, which is expected to examine the relationship between the press and the police, was put on hold because of the court cases that were in progress at the time. Cathcart (2018) argues that the second part of the Inquiry should not be shelved because the press refused to act on the findings of the first part of the Leveson Inquiry; the press failed to reform themselves; only Leveson 2 can reveal whether lawbreaking has ceased in the industry; cancellation would be a breach of political trust (government's promise to press victims); more needs to be revealed in order to build public trust in journalism; the cancellation of Leveson 2 ought to have been a cross-party action, not the action of only one party; and that without Leveson 2 "history will repeat itself" in the form of press abuse of power. Concerning the cancellation of Leveson 2, the Chairman of the Leveson Inquiry, Lord Justice Brian Leveson, said revelations after the Inquiry that phone hacking was widespread in other newspapers meant that the editors lied at the Inquiry and "that would have been an interesting part of Part 2" (Leveson 2019 cited by Evans and Johnson 2019, n.p.).

Not only was Leveson 2 cancelled, the government also announced that it would repeal section 40 of the Crimes and Courts Act 2013 (Mayhew 2018) which was the "carrot" meant to lure publishers to sign 
up to a Royal Charter-approved regulatory body such as IMPRESS (Leveson 2012a, pp. 16-17, para. 68-69). Section 40 of the Crimes and Courts Act 2013 compels newspapers to pay the costs of legal action against them even if they win, if they have failed to sign up to a cross-party Royal Charter-recognised regulator (Parliamentary Communications Committee on the Crimes and Courts Act 2013). As of 2019, none of the mainstream newspapers, not even the Guardian newspaper which supported the establishment of the Royal Charter on press regulation, signed up to IMPRESS, which was at the time the only Royal Charter-approved regulator (IMPRESS 2019). Though it can be argued that some grounds were achieved in the fight for press reform, the government's decision to shelve Leveson 2 and to revoke section 40 of the Crimes and Courts Act 2013 demonstrates the difficulty in achieving effective media reforms through government intervention.

The government and the press are self-interested parties in media reform. Reneging on or rejection of stringent proposals towards reforming the media is another recurrent outcome of efforts at effective press regulation. It can be argued that this is one of the results of the reciprocal relationship between the media and policymakers, a situation in which favours are rendered in return for good press coverage. This shall be elaborated on in Chap. 9. Tensions relating to press regulation remained at the time of writing. Some of the key tensions relate to the effectiveness of post-Leveson press regulation in the UK. There have been criticisms on IPSO's operations relating to accuracy, misleading information, placement of corrections, inaction, omission, lack of independence and the powers conferred on IPSO's Regulatory Funding Company (RFC-IPSO's version of PressBoF). As this book's focus in relation to press regulation is how arguments relating to the subject were covered by the press, I will not expand on these key tensions. Future literature can take this further by critically analysing the key tensions of press regulation after the Leveson Inquiry. The knowledge on press regulation provided in this chapter will facilitate an understanding of my analysis later in this book, of how the press covered the debate on press regulation and the implication of their manner of coverage for strong media reforms and democracy. 


\section{Conclusion}

Arguments related to press regulation in media policy debates often border around whether to create more stringent regulations in order to make the press accountable or to steer clear of any further regulation in the interest of a free press that can hold power to account. Arguments relating to more stringent regulation often include discussions about whether to introduce some level of statutory regulation. This chapter pointed out that the British press is averse to statutory regulation. Its resistance to statutory regulation has been recurrent in debates about media policy from the 1949 Royal Commission on the Press to the Leveson Inquiry (2011-2012). The press' response to such threats from the government has been to set up new self-regulatory bodies that promise to be better than the previous and capable of ensuring that the press is accountable. However, from 1949 to the time of writing, complaints have been that such bodies have not succeeded in this role.

For instance, the PCC which was created as an improved regulator following threats of statutory regulation was declared incompetent by the Leveson Inquiry. IPSO which replaced the PCC now receives similar criticism from media reform campaigners. The questions this raises are as follows: Does self-regulation of the press work? Should the paradigm of self-regulation as a prerequisite for a free press be re-examined? Can some level of statutory regulation of the press enhance democracy? These questions will continue to produce opposing views. This book argues that how these views are covered by the press matters. Equal attention should be given to the various arguments relating to press regulation so that neither the press nor the public is unduly advantaged in the representations of debates about press regulation.

Currently, the debate about how to make the press accountable is very narrow. Much of the talk focuses on statutory regulation. While some level of statutory regulation can be an option, the press needs to provide an environment that can allow debates to be more robust so that other options can emerge. There is need for more creativity with regard to how to make the press more accountable. This book argues that such creativity can emerge if the media serve as a democratic public sphere in debates about press how to make the press more accountable. The attitude of the press should not be to fight to protect the status quo but an open mind to find out the best way to achieve press accountability, a way that ensures that the freedoms of both the public and the press are protected. The 
following chapter expands on the role of the media as a democratic public sphere during debates on media policy. It will also introduce some of the theories and ideologies that formed the basis of some of the arguments that are analysed in this book.

\section{REFERENCES}

$B B C$ News. (2014). Andy Coulson jailed for 18 months over phone hacking. BBC News, 4 July [Online]. Retrieved June 30, from http://www.bbc.co.uk/news/ uk-28160626.

Bloy, D. (2012). Who watches the watchdog? Pacific Journalism Review, $18(2), 14-27$.

Carney, D. (2012). Fear and loathing: Media accountability after the phone hacking. In R. Keeble \& J. Mair (Eds.), The phone hacking scandal: Journalism on trial (pp. 321-344). Bury St. Edmunds: Arima Publishing.

Cathcart, B. (2018). Select committee savages IPSO for failing to protect Muslims [Online]. ByLine. Retrieved August 13, 2019, from https://www.byline.com/ column/68/article/2059.

Cathcart, B. 2019. IPSO gets a new chair, a former Tory Minister [Online]. ByLine. Available at. https://www.byline.com/column/68/article/2500. Accessed 13 Aug 2019.

Curran, J., \& Seaton, J. (2010). Power without responsibility: Press, broadcasting and the Internet in Britain (7th ed.). London: Routledge.

DCMS, \& Miller, M. (2013). Leveson report: Cross-party Royal Charter. Department of Media, Culture, and Society [Online]. Retrieved October 7, 2014, from https://www.gov.uk/government/publications/leveson-reportcross-party-royal-charter.

Evans, and Johnson, G. (2019). I knew i was being lied to by newspaper editors over phone hacking, says Sir Brian Leveson [Online]. Byline times.. Available at: https://bylinetimes.com/2019/06/21/leveson-tells-the-truth-about-presslies/.. Accessed 24 Aug 2019.

Frost, C. (2007). Journalism ethics and regulation (2nd ed.). Essex: Pearson Education Limited.

Harcup, T. (2014). A dictionary of journalism. Oxford: Oxford University Press. IMPRESS. (2016). Building public trust in journalism [Online]. Retrieved July 7 , 2017, from http://www.impress.press/.

IMPRESS. (2019). Regulated publications [Online]. Retrieved August 29, 2019, from https://www.impress.press/complaints/regulated-publishers.html.

IPSO. (2016). IPSO: Independent Press Standards Organisation [Online]. Retrieved January 10, 2017, from https://www.ipso.co.uk/faqs/pressstandards/\#what-would-happen-if-a-publisher-failed-to-uphold-expectedstandards. 
Leveson, B. (2012a). An inquiry into the culture, practices and ethics of the press. Vol. 2, pp. 437-994 [Online]. Retrieved December 27, 2016, from http:// webarchive.nationalarchives.gov.uk/20140122145022/http://www.officialdocuments.gov.uk/document/hcl213/hc07/0780/0780_ii.asp.

Leveson, B. (2012b). An inquiry into the culture, practices and ethics of the press: Executive summary [Online]. Retrieved December 27, 2016, from https:// www.gov.uk/government/uploads/system/uploads/attachment_data/ file/229039/0779.pdf.

Mayhew, F. (2018). Government closes Leveson Inquiry and pledges to repeal section 40 laws as it says focus now on "challenges" facing news industry [Online]. PressGazette. Retrieved August 29, 2019, from https://www.pressgazette.co.uk/government-closes-leveson-inquiry-and-pledges-torepeal-section-40-laws-as-it-says-focus-now-on-challenges-facing-newsindustry/.

O'Malley, T., \& Soley, C. (2000). Regulating the press. London: Pluto Press.

PCC. (2017). Press complaint commission [Online]. Retrieved July 21, 2017, from http://www.pcc.org.uk/.

Petley, J. (2013). Shouldn't freedom be good for all? British Journalism Review, $24(3), 33$.

Royal Commission on the Press. (1949). Royal commission on the press 1947-1949: Report. London: HMSO Publications.

Royal commission on the press. (1962). Royal commission on the press. In Report (pp. 1961-1962). London: HMSO publications.

Spark, D., \& Harris, G. (2010). Practical newspaper reporting. London: Sage.

Waterson, J. (2018). Leveson 2: Government to be taken to court over cancelled inquiry [Online]. Guardian, 21 May. Retrieved August 20, 2018, from https: / / www.theguardian.com/media/2018/may/21/ leveson-2-government-taken-court-over-cancelled-inquiry. 
Open Access This chapter is licensed under the terms of the Creative Commons Attribution 4.0 International License (http://creativecommons.org/licenses/ by $/ 4.0 /$ ), which permits use, sharing, adaptation, distribution and reproduction in any medium or format, as long as you give appropriate credit to the original author(s) and the source, provide a link to the Creative Commons licence and indicate if changes were made.

The images or other third party material in this chapter are included in the chapter's Creative Commons licence, unless indicated otherwise in a credit line to the material. If material is not included in the chapter's Creative Commons licence and your intended use is not permitted by statutory regulation or exceeds the permitted use, you will need to obtain permission directly from the copyright holder.

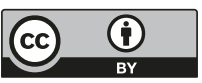

